\title{
Recolonisation of spawning grounds in a recovering fish stock: recent changes in North Sea herring
}

\author{
JÖRN O. SCHMIDT ${ }^{1,2}$, CINDY J.G. VAN DAMME ${ }^{3}$, CHRISTINE RÖCKMANN ${ }^{3}$ \\ and MARK DICKEY-COLLAS ${ }^{3}$
}

\author{
${ }^{1}$ IFM-GEOMAR, Leibniz Institute of Marine Sciences, 24105 Kiel, Germany. E-mail: jschmidt@ifm-geomar.de \\ ${ }^{2}$ Present address: Christian-Albrechts-Universität zu Kiel, Department of Economics, Sustainable Fisheries, 24118 Kiel, \\ Germany. E-mail: jschmidt@economics.uni-kiel.de \\ ${ }^{3}$ Wageningen IMARES, 1970 AB IJmuiden, The Netherlands.
}

\begin{abstract}
SUMMARY: There is evidence that the importance of the different spawning grounds of North Sea autumn-spawning herring has changed. It has been hypothesised that as herring stocks collapse, the diversity of spawning sites also collapses. This was found to be the case in the North Sea autumn-spawning herring, which collapsed in the late 1970s. The ICES International Herring Larval Survey has been carried out since 1972 and covers most of the potential and historic spawning grounds of herring. The recovery of the stock did take place as predicted in terms of biomass, and re-colonisation of old spawning sites also did occur. We show that, despite the delayed response in re-colonisation of the southern spawning areas, there is almost no change in the number of spawning locations where the highest abundances of larvae (top 50\%) are found from collapse to recovery (approximately 9 sites). It was a change in these core sites and the spread to other locations with lower larval abundance that caused the spread of herring spawning. We show that larval surveys are a useful tool for describing the dynamics of sub-stock structure in heterogeneous populations such as herring.
\end{abstract}

Keywords: spatial diversity, larvae survey, IHLS, re-colonisation, downs.

RESUMEN: RECOLONIZACIÓN DE LAS ÁREAS DE REPRODUCCIÓN EN UN STOCK DE PECES EN RECUPERACIÓN: RECIENTES CAMBIOS EN EL ARenque del Mar del Norte. - Hay pruebas de que la importancia de las diversas zonas de desove de otoño del arenque del Mar del Norte han cambiado. Existe la hipótesis de que cuando las poblaciones de arenque colapsan la diversidad de los lugares de desove también colapsan. Este fue el caso del arenque desovante de otoño en el Mar del Norte, que se derrumbó a finales de 1970. La campaña de larvas de arenque internacional ICES se ha llevado a cabo desde 1972 y cubre la mayoría de las zonas de desove, potenciales o históricas, del arenque. La recuperación de la población se llevó a cabo como se predijo en términos de la biomasa y también ocurrió la recolonización de los antiguos lugares de desove. Se demuestra que a pesar de la demora en la respuesta en el restablecimiento de la colonización de las zonas de desove del sur no hay casi ningún cambio en el número de lugares de desove, en los que la abundancia de larvas fue la más alta $(>50 \%)$ desde el colapso a la recuperación (alrededor de 9 sitios). Se trata de un cambio en estos lugares centrales y la propagación a otros lugares con menor abundancia de larvas que producen la propagación del arenque desovante. Se demuestra que las campañas de larvas son una herramienta útil para describir la dinámica de la estructura de sub-stocks en poblaciones heterogéneas, como las de arenque.

Palabras clave: diversidad espacial, campañas de larvas, IHLS, recolonización, altibajos.

\section{INTRODUCTION}

Fish stocks in the different stages of collapse or recovery show many changes in population demographics, ecology and productivity (Shelton et al., 2006; Melvin and Stephenson, 2007; Nash et al., 2009). One of the classic examples of a fisheries- induced collapse followed by stock recovery is North Sea herring (Simmonds, 2007). The collapse of North Sea herring was not spatially homogeneous. Spawning components collapsed from south to north (Cushing, 1992) and the herring became more limited in distribution (Saville and Bailey, 1980). Recovery was also different for each spawning com- 
ponent (Burd, 1985; Corten, 1999). A stock is usually viewed as recovered when the biomass has passed a particular threshold (ICES, 1997): $\mathrm{B}_{\lim }$ as a biomass threshold below which recruitment is reduced and becomes density-dependent, and $\mathrm{B}_{\mathrm{pa}}$, introduced in 1997 , as a precautionary point to $\mathrm{B}_{\text {lim }}$. However this approach does not account for recovery in terms of spatial diversity, which can have implications for the productivity of the stock and its role in the ecosystem (Nash et al., 2009; Payne et al., 2009). The environment also impacts on the spatial diversity and productivity of a stock, and there are many examples in herring of such phenomena (Bohuslän, Norwegian spring-spawning herring, the Russell cycle, see Alheit and Hagen, 1997). These variations make the sensitivity to fishing even greater.

It is widely accepted that the abundance of newly hatched larvae of North Sea herring is proportional to the biomass of spawning herring, as basically described by Postuma and Zijlstra (1974), reviewed by Heath (1993) and tested with an optimised survey design and analysis by Gröger et al. 2001. Such relationships have been found in other herring stocks as well, including Gulf of Maine, Norwegian spring spawners, Irish Sea and the Blackwater herring (Hempel and Schnack, 1971; Anthony and Fogerty, 1985; Burd, 1985; Fox 2001). Newly hatched North Sea herring larvae have been surveyed throughout most of the last 40 years. This time series of ichthyoplankton surveys thus provides a tool for describing the spatial distribution of North Sea herring spawning and the pattern of re-colonisation. It also allows us to consider whether the stock has recovered in terms of spatial distribution as well as biomass. The aim of this paper is to use the time series to describe changes in relative importance of spawning areas in order to assess the spatial recovery of the stock.

\section{MATERIALS AND METHODS}

The abundance of newly hatched herring larvae has been surveyed by the International Herring Larvae Surveys since 1972. The surveys cover the four historic spawning areas and times of North Sea autumn- and winter-spawning herring (Fig. 1). The surveys used a Gulf III or a Gulf VII sampler (Nash et al., 1998) deployed in a double oblique manner to $5 \mathrm{~m}$ above the sea bed (see ICES 2008a for full methods). The samples were fixed and in the laboratory ichthyoplankton were sorted, identified and

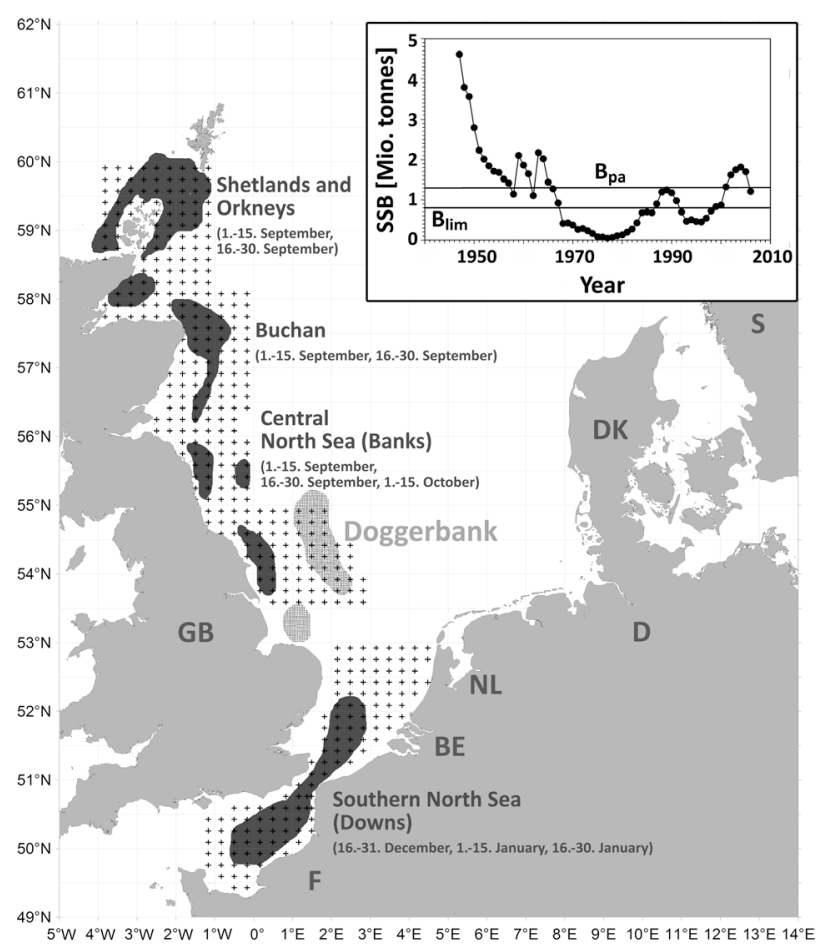

FIG. 1. - Recent (dark grey) and historic (light grey) spawning grounds of North Sea autumn- and winter-spawning herring (sampling periods in brackets); the small crosses indicate the station grid of the International Herring Larval Survey (IHLS). Spawning grounds redrawn from Nash et al. (2009) and Hodgson (1957). Inset shows the time series of spawning stock biomass (SSB) of North Sea herring, plus the SSB threshold biomass reference point.

measured. For each of the four spawning areas an index of abundance (LAI) was calculated for larvae smaller than $10 \mathrm{~mm}$ (11 mm for the Southern North Sea), as described in the manual for the International Herring Larvae Survey (ICES, 2006) and Groeger et al. (2001):

$$
L A I_{\text {year }, 30 * 30 \text { rect }}=\overline{n / m^{2} \text { year }, 30 * 30 \text { rect }} * \text { Area }_{30 * 30 \text { rect }}
$$

where $\mathrm{n} / \mathrm{m}^{2}$ vear, $30 * 30$ rect is the mean number per $30 * 30$ $\mathrm{nm}$ rectangle of a given year, consisting of 9 stations and Area $_{30 * 30 \text { rect }}$ is the area of the given rectangle. The LAI per unit (Shetland/Orkney, Buchan, Central North Sea and Southern North Sea) is calculated as follows:

$$
L A I_{\text {year, unit }}=\sum L A I_{\text {year }, 30 * 30 \text { rect }}
$$

For each year the proportion of the LAI of each unit was calculated as the proportion of the total LAI for all units for that year. The time series of spawning stock biomass of North Sea herring was taken from the recent working group report (ICES, 2008b). 


\section{Area spread}

For each year all stations (as midpoints of $10 * 10$ $\mathrm{nm}$ rectangles) were ranked according to the relative number of larvae sampled at each station. The number of stations summing up to $50 \%$ and $90 \%$ of the total number of larvae of the smallest size group for one year were taken to show the spatial extent of spawning activity.

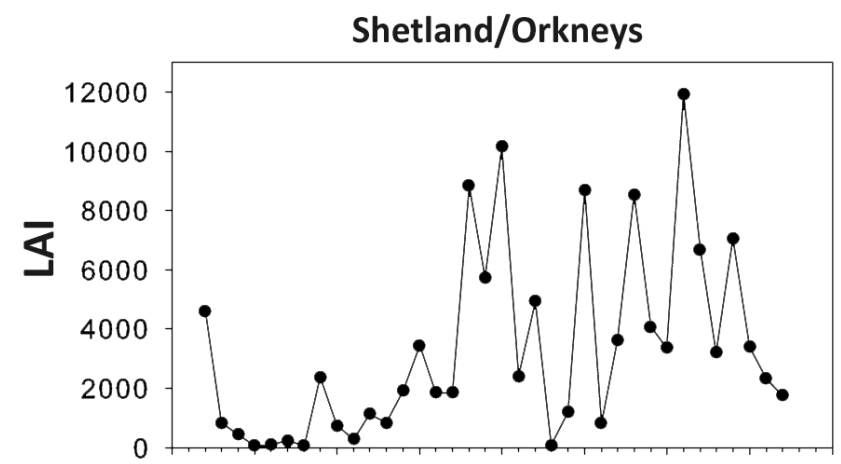

197019751980198519901995200020052010

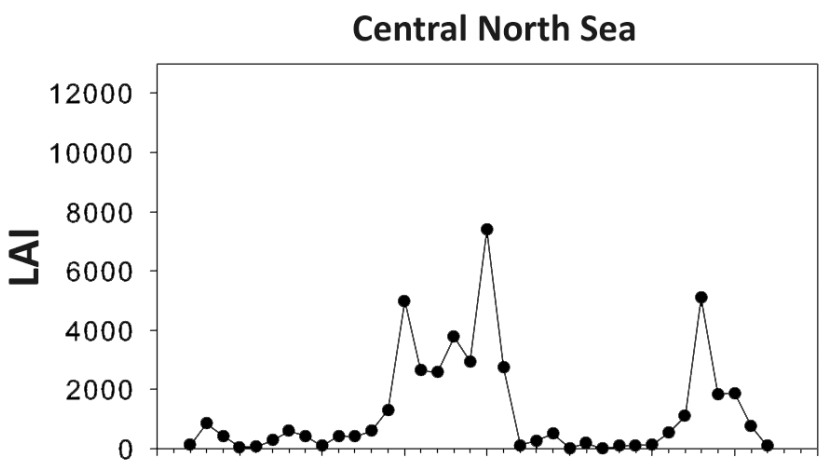

197019751980198519901995200020052010

Year

\section{RESULTS}

After the collapse in the late 1970s, the herring spawning stock recovered to above the biomass threshold $\left(\mathrm{B}_{\text {lim }}\right)$ of 800000 tonnes by the mid 1980 s. As $B_{\text {lim }}$ was the only reference point at that time, it has been considered as recovered (Fig. 1). The biomass then decreased again and management measures were brought in to reduce fishing pressure (Simmonds, 2007). In the
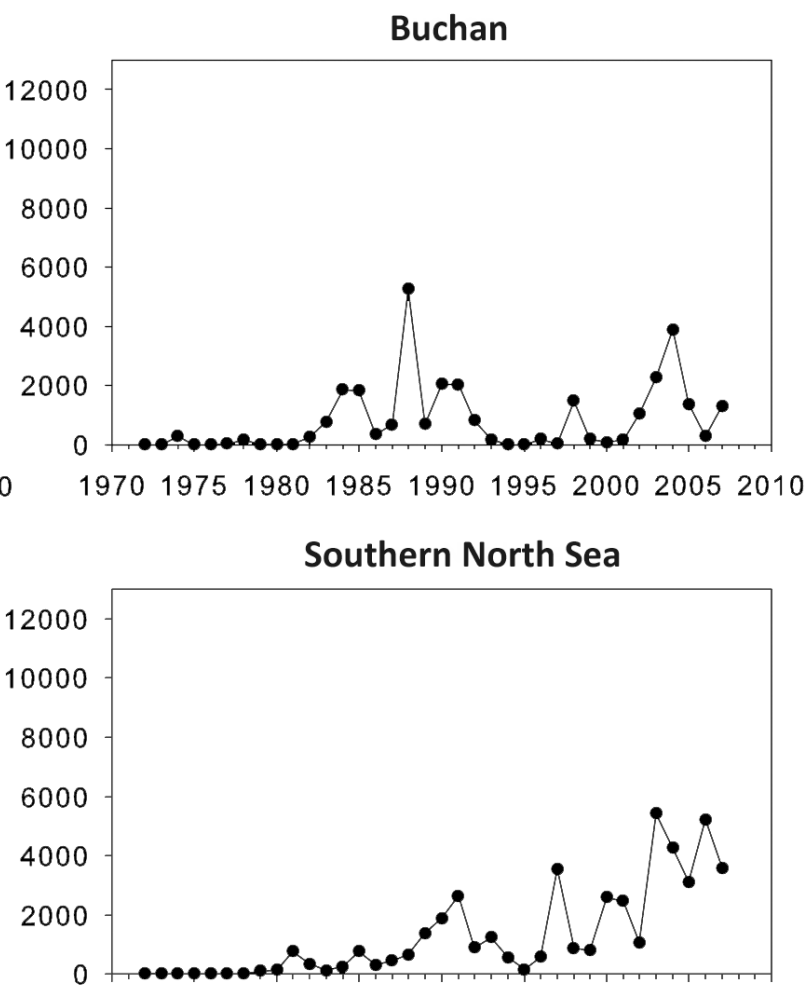

197019751980198519901995200020052010

Year

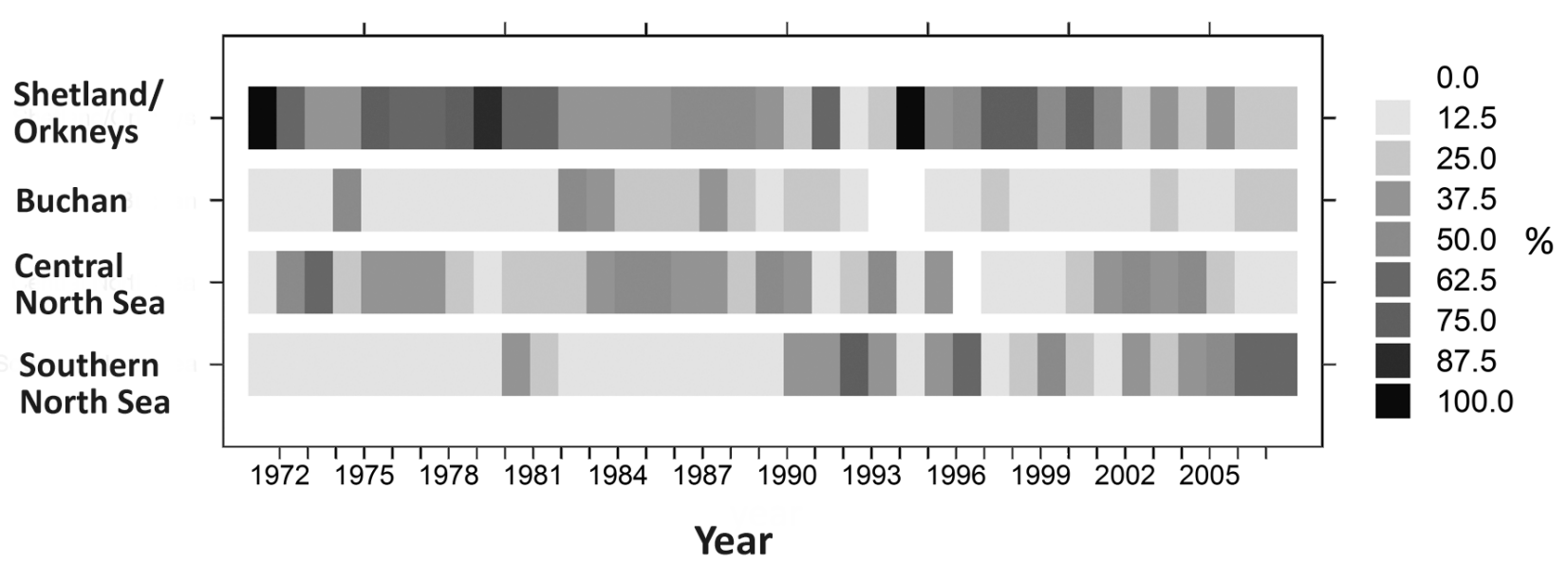

FIG. 2. - Top four panels: time series of larval abundance index (LAI) for the four herring spawning areas in the North Sea. Lower panel: relative importance of individual spawning areas, shown by the proportion; each subarea contributes to the total area in the abundance of newly hatched larvae for a given year. 
late 1990s the biomass increased again beyond $\mathrm{B}_{\lim }$ and furthermore beyond the 1.3 mil tonne threshold $\mathrm{B}_{\mathrm{pa}}$. The early part of the time series of herring larvae abundance shows that the northernmost spawning components were the last to collapse (Fig. 2). The time series also shows an increase in abundance in the late 1980s, but the increase did not occur simultaneously or in the same magnitude in all areas (Fig. 2). The initial "recovery" was almost entirely due to an increase in biomass of the Orkney/Shetland component, and was not replicated in the south, whereas the later population increase in the late 1990s was observed in the larval abundance in all areas. In the most recent years, the abundance in the southern North Sea is higher than in the Orkney/Shetland component. In terms of relative importance of larval abundance, the Orkney/Shetland spawning component dominated until at least the early 1990s (Fig. 2), and recently the southern North Sea component (which is also called Downs) has produced the majority of herring larvae in the North Sea.

This broader change in distribution masks another underlying factor. The number of locations (rectangles of $10 * 10 \mathrm{~nm}$ ) with the highest abundances of larvae (50\% of abundance per year) has remained virtually unchanged from collapse to recovery at approximately 9 (coefficient of variation $=50 \%$, Fig. 3 ). It is the remaining less productive areas (with 50 to $90 \%$ of larval abundance i.e. periphery spawning sites) that have increased in number (Fig. 3). The recovery in biomass in the mid-1980s can be seen in the increase of periphery sites, as can the decline with the reduction of biomass in the mid 1990s, although there is an overall increasing trend in number of periphery sites from 1972 to 2006.

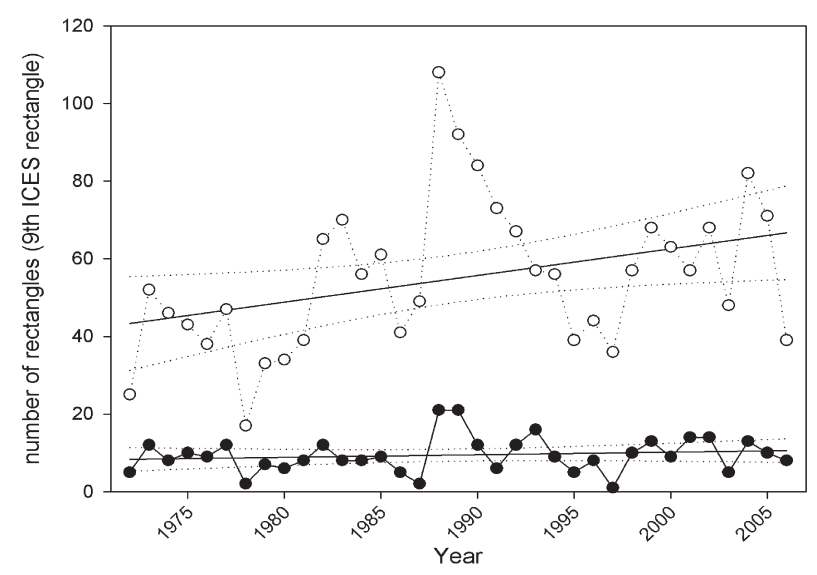

FIG. 3. - Number of rectangles (rectangles of $10 * 10 \mathrm{~nm}$ ) which constitute the 50\% (dark circles) and 90\% (clear circles) highest abundance values observed for herring larvae per year. Lines denote regression with $95 \%$ confidence intervals. The increasing trend of the $90 \%$ line is statistically significant $(\mathrm{p}<0.05)$.

\section{DISCUSSION}

As stated above, just because a stock has recovered above a biomass threshold does not necessarily mean that that stock has fully recovered. Maintaining spatial diversity is as important as rebuilding total numbers, because diversity provides resilience to local changes in environment, exploitation and fish behaviour (McPherson et al., 2001). Ichthyoplankton surveys have allowed us to monitor the abundance of newly hatched larvae and thus the spatial dynamics of the spawning biomass of herring. This information by spawning component is at present not available from any other source. Assessing the distribution by area suggests that the "recovery" in the 1980s was almost only in the northern area, so it cannot be considered as a general recovery of the North Sea herring stock. The spread of newly hatched larvae across more spawning sites suggests that recovery was more widespread by the late 1990s. However, there are still no larvae being caught on the Dogger Bank spawning site as part of the Central North Sea (Banks herring, Fig. 1), so complete re-colonisation has yet to occur.

The number of core spawning sites was maintained throughout the collapse and recovery but the core distribution shifted from north to south (Figs. 2 and 3). In addition, the increase in the number of the periphery sites indicates a wider re-colonisation. A previous shift between the spawning grounds was reported in the 1940s to 1950 s, when the spawning moved from the Shetland/Orkney to the Buchan area followed by a reversal of this shift in the 1960s (Glover, 1957; Bainbridge and Forsyth, 1972). As the productivity of spawning sites also varies due to environmental or other factors (Dickey-Collas et al., 2001), it is difficult to determine what a total re-colonisation should be, and thus to declare that a stock has recovered in total. It could also be possible that this plastic ability to shift over generations between spawning sites is a buffer against short-term and localised environmental variability.

The processes that drive the re-colonisation of spawning grounds are unclear but recolonisation is thought to be caused by large year classes or migrants "re-discovering" the grounds or "re-learning" the migration routes (McQuinn, 1997; Corten, 2001). The time taken for the re-colonisation of the southern spawning grounds (approximately 25 years) also suggests that conservation measures may not have an immediate effect, and if the objective of management is to maintain spatial diversity, then monitoring 
of each spawning component is important. Whether management should conserve the core sites or the peripheral sites is unclear, particularly as they also appear to shift with time (Fig. 2). The maintenance of a number of core spawning sites (Fig. 3) throughout collapse and recovery conforms to the classic "basin effect" (MacCall 1990) and further adds to the observations of Saville and Bailey (1980) that collapse resulted in a shrinkage in the number of occupied spawning sites. However, these core sites are still important for larval production when the stock has recovered. The recent dip in the abundance of larvae in the north is likely to have been caused by changes in the environment (see Nash and Dickey-Collas, 2005; Payne et al., 2009), and if this continues it may result in another non-anthropogenic change in the relative distribution and spatial heterogeneity of herring larvae in the North Sea.

\section{ACKNOWLEDGEMENTS}

This study was only possible thanks to the work of the scientists who have created the time series of abundance of herring larvae in the North Sea since 1970. In recent years this survey has been maintained by the German and Dutch governments. The time series is managed under the auspices of ICES and the Herring Assessment Working Group. Comments from two anonymous referees and the editor greatly improved the manuscript. Cindy van Damme, Christine Röckmann and Mark Dickey-Collas were partially supported by the EU UNCOVER project (Contract Number: 022717).

\section{REFERENCES}

Alheit, J. and E. Hagen. - 1997. Long-term climate forcing of European herring and sardine populations. Fish. Oceanogr., 2: 130-139.

Anthony, V.C. and M.J. Fogarty. - 1985. Environmental effects on recruitment, growth and vulnerability of Atlantic herring (Clupea harengus harengus) in the Gulf of Maine Region. Can. J. Fish. Aquatic. Sci., 42: 158-173.

Bainbridge, V. and D.C.T. Forsyth. - 1972. An ecological survey of a Scottish herring fishery. Part V: The plankton of the northwestern North Sea in relation to the physical environment and the distribution of the herring. Bull. Mar. Ecol., 8: 21-52.

Burd, A.C. - 1985. Recent changes in the central and southern North Sea herring stocks. Can. J. Fish. Aquatic Sci., 42(Suppl 1): $192-206$

Corten, A. - 2001. Herring and Climate. Changes in the distribution of North Sea herring due to climate fluctuations. Ph.D. thesis, Rijksuniversiteit Groningen.

Corten, A. - 1999. The reappearance of spawning Atlantic herring (Clupea harengus) on Aberdeen Bank (North Sea) in 1983 and its relationship to environmental conditions. Can. J. Fish.
Aquat. Sci., 56: 2051-2061.

Cushing, D.H. - 1992. A short history of the Downs stock of herring. ICES J. Mar. Sci., 49: 437-443.

Dickey-Collas, M., R.D.M. Nash and J. Brown. - 2001. The location of spawning of Irish Sea Herring (Clupea harengus). $J$. Mar. Biol. Ass. UK., 81: 713-714.

Fox, C.J. - 2001. Recent trends in stock-recruitment of Blackwater herring (Clupea harengus L.) in relation to larval production. ICES J. Mar. Sci., 58: 750-762.

Glover, R.S. - 1957. An ecological survey of the drift-net herring fishery off the north-east coast of Scotland. Part II: The planktonic environment of the herring. Bull. Mar. Ecol., 5: 1-43.

Groeger, J., D. Schnack and N. Rohlf. - 2001. Optimisation of survey design and calculation procedure for the international herring larvae survey in the North Sea. Arch. Fish. Mar. Res., 49 (2): 103-116

Heath, M. - 1993. An evaluation and review of the ICES Herring Larval Surveys in the North Sea and adjacent waters. Bull. Mar. Sci., 53(2): 795-817.

Hempel, G. and D. Schnack - 1971. Larval abundance on spawning grounds of banks and downs herring. Rapp. P.-v. Réun. Cons. Int. Explor. Mer, 180: 94-98.

Hodgson, W.C. - 1957. The herring and its fishery. London, Routledge and Kegan Paul.

ICES. - 1997. Report of the study group on the precautionary approach to fisheries management. ICES C.M. 1997/Assess:7.

ICES. - 2006. Report of the planning group on herring surveys. ICES C.M. 2006/LRC:04, $239 \mathrm{pp.}$

ICES. - 2008a. Report of the planning group on herring surveys. ICES C.M. 2008/LRC:01, 256 pp.

ICES. - 2008b. Report of the herring assessment working group for the area south of $62^{\circ} \mathrm{N}$. ICES C.M. 2008/ACOM:02.

MacCall, A.D. - 1990. Dynamic Geography of Marine Fish Populations. University of Washington Press, Washington.

McPherson, A.A., Stephenson, R.L., O'Reilly, P.T., Jones, M.W., and Taggart, C.T. - 2001. Genetic diversity of coastal Northwest Atlantic herring populations: implications for management. J. Fish Biol, 59A: 356-370.

McQuinn, I.H. - 1997. Metapopulations and the Atlantic herring. Rev. Fish Biol. Fish., 7: 297-329.

Melvin, G.D. and R.L. Stephenson. - 2007. The dynamics of a recovering fish stock: Georges Bank herring. ICES J. Mar. Sci., 64: 69-82.

Nash, R.D.M., M. Dickey-Collas and S.P. Milligan. - 1998. Descriptions of the Gulf VII/Pro-Net and MAFF/Guildline unencased highspeed plankton samplers. J. Plankton Res., 20: 1915-1926.

Nash, R.D.M. and M. Dickey-Collas. - 2005. The influence of life history dynamics and environment on the determination of year class strength in North Sea herring (Clupea harengus L.). Fish. Oceanogr., 14: 279-291.

Nash, R.D.M., M. Dickey-Collas and L.T. Kell. - 2009. Stock and recruitment in North Sea herring (Clupea harengus); compensation and depensation in the population dynamics. Fish. Res., 95: $88-97$.

Payne M.R., E.M.C. Hatfield, M. Dickey-Collas, T. Falkenhaug, A. Gallego, J. Gröger, P., Licandro, M. Llope, P. Munk, C. Röckmann, J.O. Schmidt and R.D.M. Nash. - 2009. Recruitment in a changing environment: the 2000s North Sea herring recruitment failure. ICES J Mar Sci., 66: 272-277.

Postuma, K.H. and J.J. Zijlstra. - 1974. Larval abundance in relation to stock size, spawning potential and recruitment in North Sea herring. In: J.H.S. Blaxter (ed.), The early life history of fish, pp. 113-128. Springer-Verlag, Berlin.

Saville, A. and R.S. Bailey. - 1980. The assessment and management of the herring stocks in the North Sea and to the west of Scotland. Rapp. Proc.-Verb. Réun. Cons. Int. L'Éxplor. Mer, 177: 112-142

Shelton, P.A., A.F. Sinclair, G.A. Chouinard and R. Mohn. - 2006. Fishing under low productivity conditions is further delaying recovery of Northwest Atlantic cod (Gadus morhua). Can. J. Fish. Aquat. Sci., 63: 235-238.

Simmonds, E.J. - 2007. Comparison of two periods of North Sea herring stock management: success, failure, and monetary value. ICES J. Mar. Sci., 64: 686-692.

Received November 17, 2008. Accepted June 25, 2009.

Published online October 5, 2009. 